\title{
Analisis Parameter Fisik, Kimia, Biologi, dan Daya Dukung Lingkungan Perairan Pesisir Untuk Pengembangan Usaha Budidaya Udang Windu di Kabupaten Barru
}

\author{
Rustam \\ Fakultas Perikanan dan IImu Kelautan Universitas Muslim Indonesia Makassar \\ Diterima 28-09-2009 Disetujui 25-01-2010
}

\begin{abstract}
The regency of Barru is a potential region for Tiger prawn cultured in the South Sulawesi Province. Generally, this aquaculture activity is based on the application of intensively cultivated pattern by using artificial feed as a source of the prawn foremost meal. Some research suggested that an intensive pattern of prawn cultured generates some waste products that are significantly to affect such physical, chemical as well as biological parameters of coastal water condition. That the change in environmental quality of coastal water will affect commercial tiger prawn that is the role of water to support sustainable cultured through its carrying capacity. This research was aimed to analyze physical, chemical and biological parameters of coastal water and to ensure its carrying capacity in maintaining commercially tiger prawn cultured. The results are expected to be some more valuable references for the benefit of the development of tiger prawn aquaculture. The research was conducted in the coastal water from June to December 2007. Observation was made in order to find out physical, chemical, and biological factors throughout the stations (i.e., sea, coastal, pond, estuaria and the outlet of the farm stations). To examine the physical, chemical and biological parameter of spatial characteristic, a Principal Component Analysis (PCA) was used. The used approaches to determine carrying capacity were based on capacity and receivance ability of waters and oxygen content. The results of this research show that the entirely physical and chemical parameters of coastal water of the Barru regency were exceeded that of the requirement thresholds of the total suspended sediment (TSS) and the chemical oxygen demand (COD). A spatial distribution of physical and chemical characteristics was measured high by TSS and COD, as well as the level of water turbidity, all at the outflow of estuaria and the Outlet; meanwhile, the value of $\mathrm{NO}_{2}$, Phosphate, and $\mathrm{NH}_{3}$ substances was recorded high at the pond. A biological parameter was characterized by the existence of phytoplankton through its density and abundance as well. Those of the Class Bacyllariophyceae was dominantly encountered to attain at the top as high as $75.2 \%$ in species composition, followed by Cyanophyceae $9.3 \%$ at the second, and the rest Chlorophyceae $8.9 \%$ and Dyanophyceae and Euglenophyceae $5.9 \%$ and $0.7 \%$ respectively. Based on the stationed preferences, those in the coastal, the pond, and the Outlet were dominated by Bacyllariophyceae, whereas the estuaria by Cyanophyceae. The Shannon's index of diversity $\left(H^{\prime}\right)$ of the entirely stations was varied among 1.01-2.12 that the lowest one at the estuaria and the highest at the sea. The coastal water has its carrying capacity to support the excess of 506,437 $\mathrm{kg}$ organic waste substances based on the necessity of oxygen content suspending in the water column. Therefore, the given pond is feasible to develop to reach as much as $219 \mathrm{Ha}$ intensive ponds, or $481 \mathrm{Ha}$ semi-intensive ponds on the other way.
\end{abstract}

Keywords: biological, carryng capacity, chemical, parameters fhysical, tiger prawn

\section{PENDAHULUAN}

Luas lahan pertambakan di Sulawesi Selatan meliputi 15.900 hektar dan 84.832 hektar dipergunakan untuk tambak (Departemen Kelautan \& Perikanan, 2006). Hal ini menunjukkan bahwa pemanfaatan lahan untuk pertambakan telah menunjukkan pemanfaatan yang berlebihan (over exploited). Kabupaten Barru merupakan salah satu daerah pertambakan udang di Sulawesi Selatan yang tingkat teknologinya mengalami perkembangan. Meningkatnya teknologi pertambakan udang tersebut, menimbulkan permasalahan di

Telp: +62811469156

Email: rustam_umi@yahoo.com kawasan pesisir yaitu tingginya buangan limbah organik yang dihasilkan oleh kegiatan pertambakan udang. Hitungan besarnya limbah tambak yang lebih sederhana diberikan oleh Annchhatre dan Jeganaesan (2006) sebagai berikut. Tambak udang intensif dengan luas $4000 \mathrm{~m}^{2}$, tingkat kepadatan $30 \mathrm{ekor} / \mathrm{m}^{2}$, jumlah pakan yang diberikan sebanyak 2 ton dengan kadar protein $35-50 \%$, limbah organik yang terbuang ke perairan sebanyak $900 \mathrm{~kg}$.

Limbah organik yang berupa sisa pakan dan sisa metabolisme dari hasil kegiatan pertambakan udang akan terbuang ke perairan pesisir melalui pergantian air. Buangan air dari kegiatan pertambakan udang 
tersebut akan mempengaruhi kondisi fisik, kimia dan biologi lingkungan perairan pesisir sebagai penerima limbah. Disamping itu juga akan mempengaruhi kegiatan usaha pertambakan udang sebagai sumber air untuk kegiatan pertambakan

Berdasarkan hal tersebut, agar usaha pertambakan udang di daerah Kabupaten Barru Sulawesi Selatan berkelanjutan, maka diperlukan penelitian tentang analisis farameter fisik, kimia dan biologi perairan dan daya dukung lingkungan perairan pesisir sebagai salah satu dasar acuan dalam penentuan tingkat teknologi dan luas tambak yang layak dioperasikan dalam pengembangan usaha budidaya udang windu secara berkelanjutan.

\section{BAHAN DAN METODE}

Determinasi Kualitas Perairan Kawasan

Pesisir. Determinasi kualitas perairan bertujuan Untuk mengetahui kualitas perairan pesisir, maka pengambilan contoh untuk keperluan analisis faktor fisik, kimia, dan biologi perairan pesisir dilakukan pada 6 stasiun, yaitu: Stasiun I Laut yang terdiri dari 3 sub stasiun (A1,A2 dan A3), Stasiun II Pantai yang terdiri dari 6 sub stasiun (B1, B2, B3, B4, B5 dan B6), Stasiun III Pertambakan udang Intensif, semi intensif dan tradisional yang terdiri dari 6 sub stasiun (C1, C2, C3, C4, C5, dan C6), Stasiun
V Muara yang terdiri dari 3 sub stasiun (E1, E2, dan E3) dan Stasiun VI Saluran Pembuangan (outlet) yang terdiri dari 3 sub stasiun (F1, F2 dan F3). Posisi masingmasing stasiun dan substasiun pengambilan contoh tersebut di atas ditentukan dengan alat bantu Global Position System (GPS).

Pengukuran Parameter Fisik, kimia dan Biologi Perairan. Pengukuran parameter fisik, kimia dan biologi perairan ini ditujukan untuk menentukan "present status" kondisi perairan yang dapat dikaitkan dengan tingkat produktivitas budidaya tambak Metode pengambilan contoh dan analisis laboratorium mengikuti metode standard (APHA, 1989 dalam Dahuri, 1998). Identifikasi biologi (fitoplankton \& benthos) dilakukan dengan menggunakan buku identifikasi Davis, (1955) dan Yamaji, (1979). Parameter fisik, kimia dan biologi yang diamati selengkapnya disajikan pada Tabel 1 .

Analisis Parameter Fisik dan Kimia Perairan. Analisis Parameter fisik dan kimia perairan bertujuan untuk menentukan sebaran spasial karakteristik fisik kimia perairan antar stasiun pengamatan digunakan suatu pendekatan sidik peubah ganda yang didasarkan pada Analisis Komponen Utama (Principle Componen Analisis, PCA). Analisis ini adalah metode analisis deskriptif yang disajikan dalam bentuk grafik dan matriks. Matriks data yang ditampilkan terdiri dari stasiun

Tabel 1. Parameter fisika, kimia dan biologi perairan yang diamati pada penelitian

\begin{tabular}{|c|c|c|c|}
\hline No & Parameter & Alat Yang Digunakan & Analisis Laboratorium \\
\hline 1. & Suhu & Thermometer & Insitu \\
\hline 2. & Kekeruhan & Turbiditymeter & $\sqrt{ }$ \\
\hline 3. & Kecerahan & Secchidisk & Insitu \\
\hline 4. & TSS & Botol sampel \& Ice Box & $\sqrt{ }$ \\
\hline 5. & Pasang surut & Papan berskala & Insitu \\
\hline 6. & Arus & Current Meter & Insitu \\
\hline 7 & Glombang & Stopwatch, meteran & Insitu \\
\hline 8. & $\mathrm{pH}$ & $\mathrm{pH}$-meter & Insitu \\
\hline 9. & Salinitas & Hand refractomete & Insitu \\
\hline 10. & Oksigen (DO) & DO-Meter & Insitu \\
\hline 11. & Ammonia & Botol Sampel, Presevatif & $\sqrt{ }$ \\
\hline 12. & Nitrat & Botol sampel, Preservatif & $\sqrt{ }$ \\
\hline 13. & Nitrit & Botol sampel, preservatif & $\sqrt{ }$ \\
\hline 14. & Orthophosphat & Botol sampel, preservatif & $\sqrt{ }$ \\
\hline 15. & BOD5 & Botol BOD, Preservatif & $\sqrt{ }$ \\
\hline 16. & COD & Botol Sampel, Preservatif & $\sqrt{ }$ \\
\hline 17. & Fitoplankton & Botol BOD, Preservatif & $\sqrt{ }$ \\
\hline 18. & Makrozoobenthos & Botol Sampel, Preservatif & $\sqrt{ }$ \\
\hline
\end{tabular}

Keterangan : ( $\sqrt{ }=$ dianalisis di laboratorium, insitu = dilapangan) 
pengamatan sebagai variabel individu (baris) dan parameter kualitas air sebagai variabel kuantitatif (kolom).Hasil akhir analisis komponen utama yaitu ada tidaknya perbedaan sebaran spasial parameter fisikkimia perairan antar berbagai titik pengamatan. Analisis Komponen Utama ini menggunakan program Software XIstat versi 5.0.

Analisis Daya Dukung Kawasan Perairan Pesisir. Analisis daya dukung kawasan perairan pesisir untuk usaha pengembangan pertambakan yaitu pendekatan daya dukung berdasarkan analisis Hubungan antara ketersediaan oksigen terlarut dengan beban limbah. Analisis ini mengacu pada Willoughby (1968 dalam Rahmansyah, 2004) dan Boyd (1999) bahwa oksigen dibutuhkan untuk mendekomposisi limbah organik dalam perairan. Pergantian air akibat pasang surut akan menyediakan atau memasok oksigen terlarut dalam badan air.

\section{HASIL DAN PEMBAHASAN}

Pasang Surut. Pasang surut di daerah Kabupaten Barru berdasarkan nilai Formsahl yang diperoleh, maka tipe pasang surut dikategorikan sebagai pasang surut campuran dominan. Pemanfaatan tenaga pasang surut sebagai sumber penyediaan air untuk kegiatan usaha budidaya tambak, maka nilai tinggi pasang surut (amplitudo) perlu dihitung. Rata-rata tinggi pasang surut pada waktu pasang tertinggi (spring tide) adalah $98 \mathrm{~cm}$ dan pada waktu pasang terendah (neap tide) adalah $30 \mathrm{~cm}$ (Tabel 2).

Gelombang Laut. Gelombang laut di perairan pantai Kabupaten Barru sebagaimana gelombang di perairan pada umumnya, diakibatkan oleh angin yang bertiup di permukaan laut dan pasang surut muka air laut. Tinggi gelombang di peraran pantai Kabupaten Barru bervariasi menurut musim, kecepatan angin dan tinggi amplitudo pasang surut. Pada musim Barat (musim hujan), yaitu bulan Oktober - Maret gelombang lebih tinggi dibandingkan dengan pada musim Timur (April-September). Berdasarkan hasil perakiraan badan meteorologi Sulawesi Selatan tinggi gelombang pada

Tabel 2. Karakteristik Pasang Surut di Perairan Pantai Kabupaten Barru

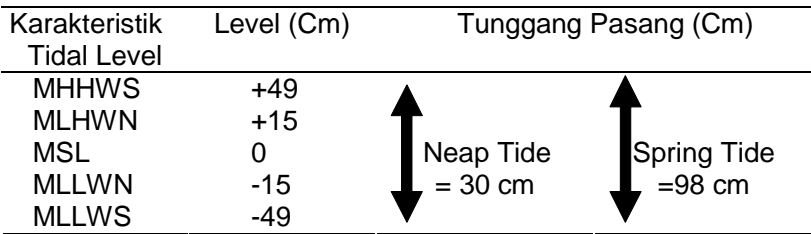

musim barat untuk kawasan perairan Kabupaten Barru dan sekitarnya mencapai 0,3-3,0 m, sedangkan pada musim timur 0,1-2,0 m.

Arus Pasang Surut. Arus pasang surut di sekitar pantai Kabupaten Barru terdiri atas arus pasang surut (tidal current), susur pantai (longshore current) dan arus tolak pantai. Arus pasang surut dibangkitkan oleh pasang surut air laut yang terjadi di daerah sebelum ombak pecah, sedangkan arus susur pantai dan tolak pantai dibangkitkan oleh ombak setelah pecah. Pola arus di pantai pada umumnya disebabkan oleh angin dan arahnya dapat dipengaruhi oleh arah angin. Hasil pengamatan di lapangan didapatkan bahwa kecepatan arus di perairan pantai Kabupaten Barru yang disebabkan oleh pasang surut berkisar $0,038-0,195 \mathrm{~m} /$ detik, dengan arah arus yang berubahubah tergantung pada keadaan pasang surut. Pada saat pasang naik arus menuju ke arah utara sebaliknya pada saat surut ke arah selatan.

Parameter Fisik dan Kimia Perairan Pesisir. Parameter fisik dan kimia perairan pesisir Kabupaten Barru yang diambil dari masing-masing stasiun pengamatan bahwa ada beberapa parameter fisik dan kimia perairan yang sudah melampaui nilai baku mutu yang diperbolehkan untuk biota laut seperti TSS (80 mg/l), COD (80 mg/l) dan Kekeruhan (30 NTU). Pada stasiun pantai parameter kualitas perairan yang melampaui nilai baku mutu biota laut yang diperbolehkan adalah TSS (125 $\pm 57,3 \mathrm{mg} / \mathrm{l})$ dan COD $(86,79 \pm 87 \mathrm{mg} / \mathrm{l})$. Tingginya TSS pada stasiun pantai diduga dipengaruhi oleh hasil buangan limbah dari kegiatan pertambakan di darat. Kenyataan tersebut ditunjang oleh tingginya nilai TSS pada stasiun pertambakan udang intensif dan semi intensif yaitu masing-masing $238,3 \pm 53,3 \mathrm{mg} / \mathrm{l}$ dan $156,3 \pm 84,4 \mathrm{mg} / \mathrm{l}$ dan stasiun pembuangan (out let) $316,4 \pm 197,8 \mathrm{mg} / \mathrm{l}$. Seperti halnya dengan TSS, tingginya COD di stasiun pantai terutama diduga berasal dari kegiatan pertanian di darat yang menggunakan bahan kimia seperti pestisida dan limbah domestik yang berasal dari pemukiman. Hal ini juga terlihat tingginya nilai COD pada stasiun sungai dan muara yaitu masing-masing $86,56 \pm 27,23 \mathrm{mg} / \mathrm{l}$ dan $82,83 \pm 15,30 \mathrm{mg} / \mathrm{l}$ yang melampaui nilai baku mutu biota laut yang diperbolehkan, stasiun ini juga merupakan tempat pembuangan limbah pertanian dan pemukiman sebelum masuk ke daerah pantai. 
Tingginya nilai TSS pada daerah pertambakan udang intensif dan semi intensif yaitu adanya pemberian pakan buatan dalam budidaya yang tidak termakan berupa sisa pakan dan hasil metabolisme berupa faeces yang terlarut ke dalam perairan (Boyd, 1998; Primavera, 1994). Selanjutnya dinyatakan bahwa pada tingkat teknologi budidaya secara intensif kebutuhan nutrisi hewan peliharaan tergantung sepenuhnya dari pakan buatan, sehingga apabila pakan buatan yang diberikan banyak yang tidak termanfaatkan maka dapat menjadi penyebab utama tingginya bahan organik dalam tambak dan selanjutnya dapat meningkatkan TSS dalam perairan tambak. Parameter lain yang memperkuat kenyataan tersebut di atas adalah tingginya nilai kekeruhan perairan pada stasiun tambak intensif $(56,9 \pm 22,1)$ dan semi intensif $(45,3 \pm 16,7)$. Menurut Effendi, (2000) terdapat hubungan yang positif antara nilai padatan tersuspensi dengan kekeruhan di suatu perairan yaitu semakin tinggi nilai padatan tersuspensi, maka semakin tinggi nilai kekeruhan.

Sebaran Spasial Karakteristik Parameter Fisik dan Kimia Perairan. Sebaran spasial karakteristik parameter fisik dan kimia perairan bertujuan Untuk mengetahui sebaran spasial antara parameter fisik dan kimia perairan dengan lokasi pengamatan dilakukan dengan menggunakan metode Principal Component Analisis (PCA) dengan program XIstat Versi 5.0. Berdasarkan hasil analisis tersebut menunjukkan bahwa ragam pada sumbu utama pertama, kedua dan ke tiga (F1,F2 dan F3) sebesar $64,05 \%$. Hal ini berarti bahwa $64,05 \%$ dari data hasil analisis dapat diterangkan hingga sumbu utama ketiga. Komponen utama pertama hingga ketiga secara berurutan menjelaskan masing-masing $39,0 \%$, $16,05 \%$ dan $9,0 \%$.

Pada sumbu pertama (F1), parameter Kecerahan, Kekeruhan, TSS, dan BOT memberikan konstribusi terbesar pada pembentukan sumbu utama pertama. Parameter TSS, Kekeruhan dan BOT berkorelasi negatif dengan parameter kecerahan yaitu apabila nilai parameter TSS, kekeruhan dan BOT tinggi, maka nilai kecerahan akan rendah. Parameter salinitas, $\mathrm{NO}_{2}, \mathrm{NH}_{3}$ dan Fosfat memiliki konstribusi terbesar terhadap pembentukan sumbu utama kedua (F2) (Gambar 1A)

Pada sumbu pertama (F1) menggambarkan bahwa satsiun $E$ dan $F$ khususnya pada stasiun $E 1, F 2$ dan F3 dicirikan oleh TSS, Kekeruhan, BOT yang tinggi.
Pada stasiun ini merupakan stasiun muara dan outlet yang merupakan tempat pembuangan dan terakumulasinya limbah organik dari tambak dan sungai. Stasiun A dan B pada seluruh pengamatan dicirikan oleh nilai kecerahan yang tinggi, khususnya pada pengamatan $A 1, A 2$ dan $A 3$. Hal ini menunjukkkan bahwa letak stasiun menentukan, yakni semakin mengarah ke laut nilai kecerahan semakin tinggi. Pada sumbu 2 (F2) stasiun C, D dan E khususnya stasiun $\mathrm{C} 5, \mathrm{D} 1, \mathrm{D} 2$,D3, E2 dan E3 dicirikan oleh nilai $\mathrm{NO}_{2}$, Fosfat dan $\mathrm{NH}_{3}$ yang tinggi. Nilai parameter fisik, kimia perairan lainnya menunjukkan distribusi yang hampir merata di seluruh stasiun (Gambar 1B)

Parameter Biologi Perairan. Parameter biologi perairan yang diamati yaitu fitoplankton dan makrozoobenthos. Berdasarkan hasil identifikasi fitoplankton diketahui bahwa paling tidak ada 5 kelas fitoplankton yang terdapat di perairan pesisir Kabupaten Barru yaitu Bacyllariophycea, Chlorophycea, Cyanophycea, Dyanophycea dan Euglenophycea, Sedangkan komposisi kelas dan kelimpahan fitoplankton yang diperoleh pada seluruh stasiun (laut, pantai, pertambakan, saluran pembuangan (outlet) dan (muara) Diketahui bahwa kelas fitoplankton Bacyllariophycea yang dominan $(75,2 \%)$, selanjutnya Cyanophyceae $(9,3 \%)$, Chlorophycea $(8,9 \%)$, Dyanophycea $(5,9 \%)$ dan Euglenophycea $(0,7 \%)$. Namun komposisi kelas dan kelimpahan fitoplankton Bacyllariophyceae mendominasi pada stasiun laut, pantai, pertambakan dan saluran pembuangan (outlet), sedangkan stasiun muara didominasi oleh kelas Cyanophyceae.

Jenis fitoplankton dari kelas Bacyllariophycea yang didapatkan adalah Chaetoceros, Nitschia, Cosconodicus dan Rhizosolenia merupakan jenis yang memiliki frekuensi kemunculan dan kelimpahan tinggi. Chaetoceros dan Nitschia ini merupakan jenis diatom yang digemari oleh udang. Kelas Chlorophyceae yang didapatkan dan frekuensi kemunculannya dan kelimpahan tinggi adalah jenis Coelastrum, Oocystis, Oodegenium,Ulothrix, dan Microsphora. Kelas Cyanophyceae yang didapatkan adalah jenis Calothrix, Oscillatoria, Trichodesmium, dan Spirulina. Kelas Dynophyceae yang didapatkan adalah jenis Ceratium dan Noctiluca. Sedangkan kelas Euglophyceae jenis yang didapatkan adalah Euglena. Hasil perhitungan nilai 


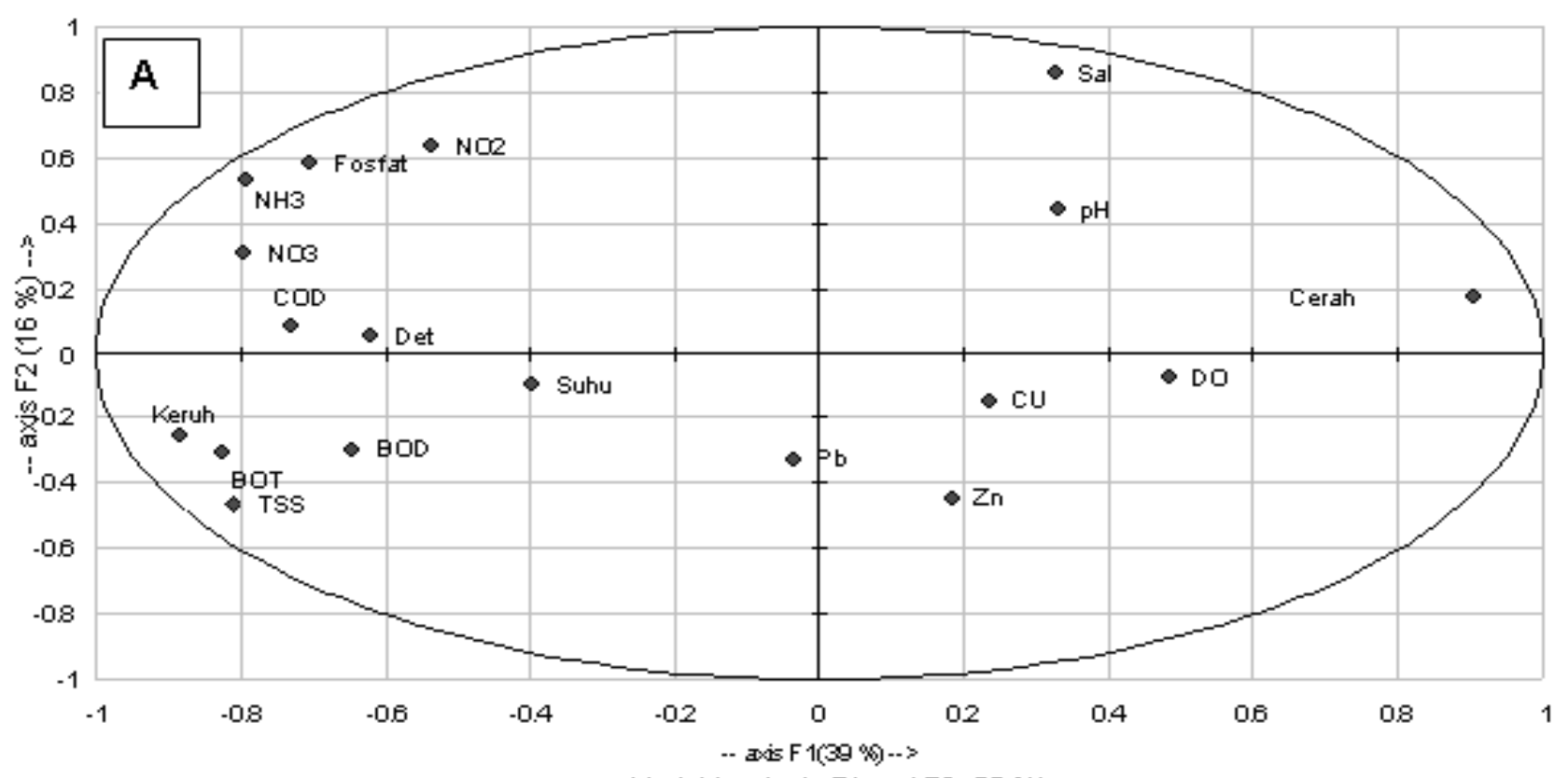

Variables (axis F1 and F2: $55 \%$ )

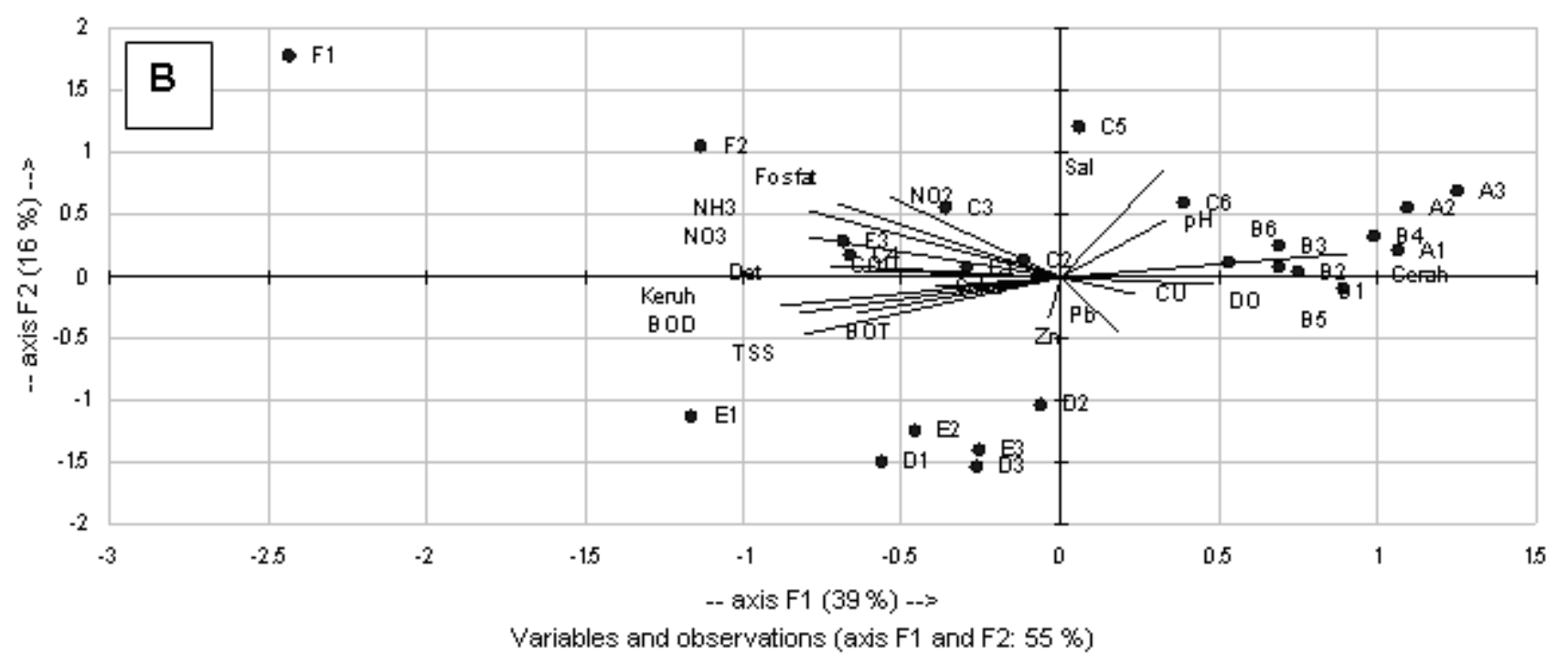

Gambar 1. Lingkaran Grafik Korelasi Parameter Fisika-kimia Perairan pada Sumbu 1 dan 2 berdasrkan Stasiun Pengamatan

indeks keragaman $\left(H^{\prime}\right)$ dan indeks keseragaman $(E)$ dari semua stasiun diperoleh kisaran nilai indek keragaman 1,01-2,12. Nilai keragaman yang terendah didapatkan pada stasiun muara dan tertinggi pada stasiun laut.

Hasil pengamatan terhadap makrozoobenthos pada masing-masing stasiun diperoleh jumlah spesies yang kecil, yaitu berkisar $1-5$ jenis dengan kepadatan rata-rata 60 individu $/ \mathrm{m}^{2}$ keadaan ini menunjukkan adanya jenis makrozobenthos yang dominan. Hal ini sesuai dengan pendapat Paez-Ozuna et al., (1998) mengemukakan bahwa apabila dalam suatu lingkungan terjadi penurunan keragaman secara tajam sampai hanya sebagian kecil saja populasi yang dominan, maka lingkungan tersebut telah mengalami tekanan akibat pencemaran dan populasi tersebut yang disebut sebagai indikator pencemaran. Analisis indeks keanekragaman makrozoobenthos yang diperoleh pada masing-masing stasiun berkisar antara 0,64 - 1,70 dengan nilai rataan 1,06. Hasil analisis indeks keseragaman jenis $(E)$ pada masing-masing stasiun diperoleh kisran 0,86-1,0 dengan nilai rataan 0,96. menurut Soewardi. (2002) apabila nilai E mendekati 1, sebaran individu antara jenis relatif merata. Sebaliknya jika nilai E mendekati 0, maka sebaran individu antara jenis tidak merata.Berdasarkan hasil analisis indeks keseragaman $(E)$ makrozoobenthos pada masingmasing stasiun pengamtana menujukkan sebaran jenis relatif merata.

Daya Dukung Kawasan Berdasarkan Ketersediaan Volume Air. Daya dukung kawasan perairan berdasarakan ketersediaan volume air dihitung 
dengan menggunakan pendekatan seperti yang dlakukan oleh Widigdo et al., (2001) dengan berdasarkan panjang garis pantai, kisaran pasang, kemiringan dasar perairan dan jarak dari garis pantai pada air pasang ke arah laut sampai mencapai titik dimana kedalaman air pada saat surut terendah yaitu satu meter sama dengan kedalaman dari pipa pengambilan (intake) air laut untuk tambak. Berdasarkan hasil pengamatan bahwa kondisi fisik perairan pesisir pantai Kabupaten Barru disajikan pada Tabel 3, sedangkan kedalaman perairan pesisir pantai disajikan pada Gambar 2.

Berdasarkan data hasil perhitungan volume air yang tersedia dipantai (Vo) didapatkan 34.729.584 $\mathrm{m}^{3}$

Tabel 3. Kondisi fisik perairan pesisir Kabupaten Barru

\begin{tabular}{ccc}
\hline Paremeter & Nilai Pengamatan & Keterangan \\
\hline Kisaran pasut $(\mathrm{h})$ & $98 \mathrm{~cm}$ & - \\
Jangkauaan pasang $(\mathrm{x})$ & $455 \mathrm{~m}$ & - \\
Lebar pantai $(\mathrm{y})$ & $78 \mathrm{~km}$ & - \\
Pola pasang surut & 2 kali pasang, 2 kali surut & Semi diurnal \\
Kemiringan pantai $(\theta)$ & $36.6^{\circ}(\operatorname{tg} 0.74)$ & \\
\hline
\end{tabular}

dan volume air yang tersedia perhari $69.459 .168 \mathrm{~m}^{3}$ ( 2 kali pasang), sedangkan volume air pada saat surut (Vs) yaitu $11.910 .600 \mathrm{~m}^{3}$. Berdasarkan nilai tersebut didapatkan bahwa luas tambak yang optimum dapat dioperasikan daerah Kabupaten Barru berdasarkan teknologi yaiitu masing-masing secara intensif hanya 694,6 ha berdasarkan target kapasitas produksi yaitu $3,5-4,0$ ton ha. Budidaya udang secara semi intensif dengan target produksi rata-rata $1,5-2,0$ ton/ha/MT, maka luas tambak yang dapat dioperasikan yaitu $1.389,2$ ha. Budidaya udang tradisional dengan target produksi $500 \mathrm{~kg} / \mathrm{ha} / \mathrm{MT}$, maka luas tambak yang dapat dioperasikan yaitu $5.556,8$ ha. Secara rinci luasan tambak udang yang dapat dioperasikan berdasarkan tingkat teknologi disajikan pada Tabel 4.

Pendugaan Daya Dukung Lingkungan Perairan Berdasarkan Ketersediaan Oksigen Terlarut dengan Limbah Organik. Pendugaan daya dukung lingkungan perairan berdasarkan ketersediaan oksigen terlarut dengan limbah organik mengacu pada Widigdo (2000), dan Boyd et al., (1998) bahwa oksigen

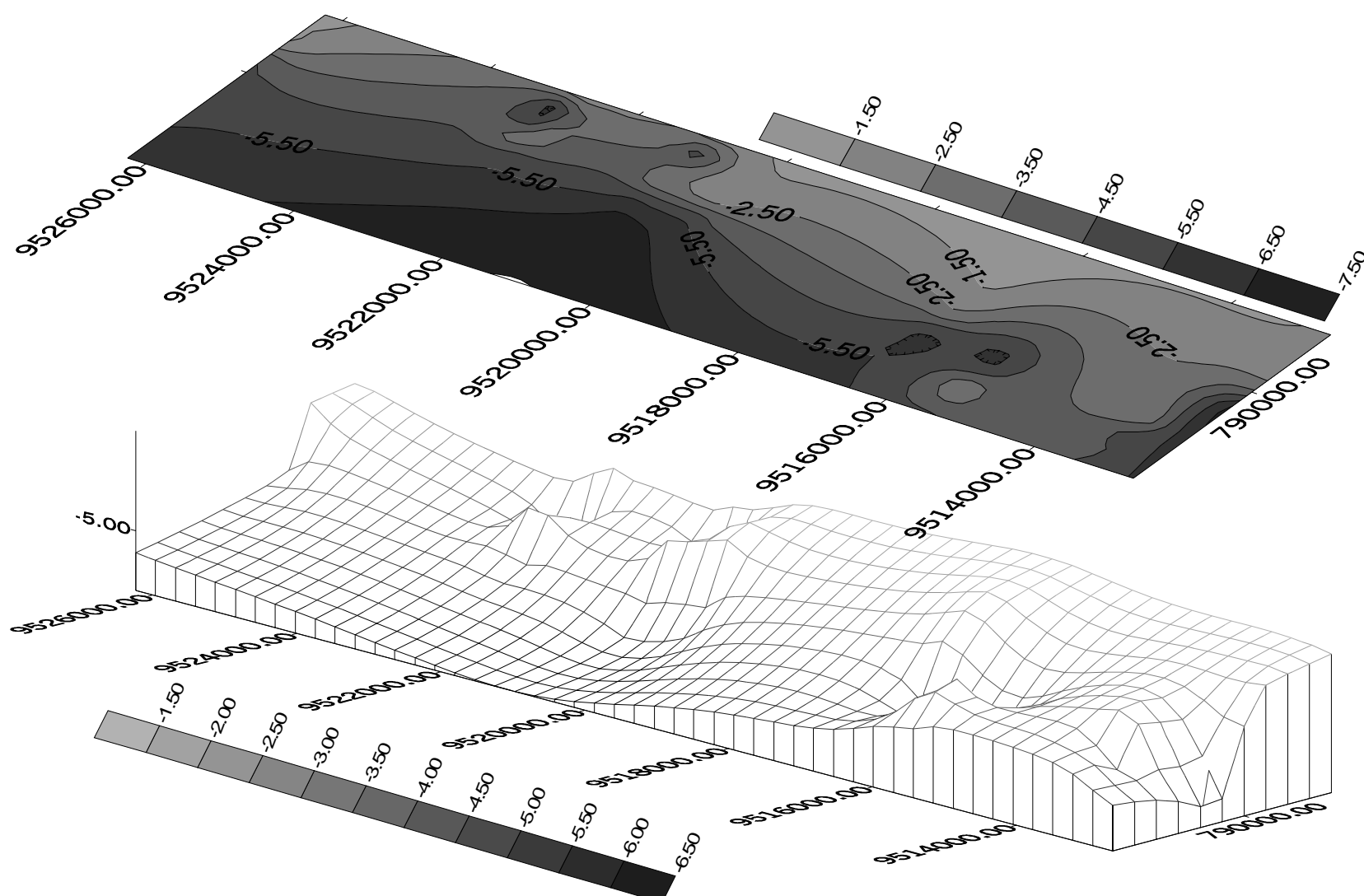

Gambar 2. Tofografi Dasar dan Kedalaman Perairan Pesisir Kabupaten Barru

Tabel 4. Luas Tambak yang Layak Untuk dioperasikan Berdasarkan Tingkat Teknologi yang didasarkan atas volume air yang tersedia

\begin{tabular}{llccc}
\hline \multirow{2}{*}{ Lokasi } & \multirow{2}{*}{ Kapasitas Produksi (Kg/MT) } & \multicolumn{3}{c}{ Luas Tambak (ha) Berdasarkan Target Produksi } \\
\cline { 3 - 5 } & \multirow{2}{*}{ Kabupaten Barru } & Intensif (4 ton/ha/MT) & Semi Intensif (2 ton/ha/MT) & Tradisional $(500 \mathrm{~kg})$ \\
\hline
\end{tabular}


dibutuhkan untuk mendekomposisi limbah organik dalam perairan. Pergantian air akibat pasang surut akan menyediakan atau memasok oksigen terlarut dalam badan air. Penentuan keteresediaan oksigen terlarut dalam badan air yaitu perbedaan antara konsenterasi $\mathrm{O}_{2}\left(\mathrm{~g} / \mathrm{m}^{3}\right)$ terlarut yang ada di dalam badan air $\left(\mathrm{O}_{\text {air }}\right)$ dan konsenterasi $\mathrm{O}_{2}\left(\mathrm{~g} / \mathrm{m}^{3}\right)$ terlarut minimal yang dikehendaki dari organisme budidaya $\left(\mathrm{O}_{\text {udang }}\right)$. Kadar minimum yang dikehendaki untuk budidaya adalah $3 \mathrm{mg} / \mathrm{l}\left(\mathrm{O}_{\text {out }}\right)$, sedangkan hasil pengamatan kadar oksigen di pantai $\left(\mathrm{O}_{\text {in }}\right)$ yang diamati selama 24 jam dengan selang waktu 3 jam rata-rata $6,5 \mathrm{mg} / \mathrm{l}$ (dibulatkan) (Tabel 5). Kadar oksigen yang dibutuhkan untuk mengurai/merombak $1 \mathrm{~kg}$ limbah organik pakan diperlukan oksigen sebesar $0.2 \mathrm{~kg}$, maka kemampuan perairan untuk menampung limbah organik yaitu $506.473 \mathrm{~kg}$ limbah organik. Hal ini berarti bahwa kemampuan perairan menampung limbah organik yang diperbolehkan dari hasil kegiatan budidaya tambak tanpa melampaui daya dukung sebesar $506.473 \mathrm{~kg}$ limbah organik.

Jika dikaitkan dengan batas kemampuan daya dukung perairan untuk menampung limbah organik berdasarkan ketersediaan oksigen sebesar $506.473 \mathrm{~kg}$ limbah organik, maka maksimum luas hamparan tambak yang dapat dioperasikan tanpa melampaui batas kemampuan daya dukung lingkungan perairan yaitu 219 ha tambak Intensif atau 481 ha tambak semi

Tabel 5. Kandungan Oksigen $\left(\mathrm{O}_{2}\right)$ mg/l di Pantai Barru selama 24 jam dengan Selang Waktu 3 jam pada tiga Stasiun pengamatan

\begin{tabular}{|c|c|c|c|}
\hline \multirow[t]{2}{*}{$\begin{array}{c}\text { Waktu Pengamatan } \\
\text { (Jam) }\end{array}$} & \multicolumn{3}{|c|}{$\begin{array}{c}\text { Stasiun Pengamatan / } \\
\text { Kandungan Oksigen (mg/l) }\end{array}$} \\
\hline & 1 & 2 & 3 \\
\hline 09.00 & 5.80 & 6.69 & 6.18 \\
\hline 12.00 & 9.23 & 6.07 & 9.68 \\
\hline 15.00 & 8.44 & 7.12 & 7.65 \\
\hline 18.00 & 6.98 & 6.44 & 6.63 \\
\hline 21.00 & 5.56 & 6.03 & 5.67 \\
\hline 24.00 & 5.19 & 5.42 & 6.05 \\
\hline 03.00 & 6.07 & 5.76 & 6.36 \\
\hline 06.00 & 5.62 & 6.34 & 6.23 \\
\hline Rataan & 6.48 & 6.23 & 6.67 \\
\hline
\end{tabular}

Keterangan : Stasiun 1,2, dan 3 yaitu stasiun pantai (B1, B2 dan B3). intensif. Apabila kapasitas produksi tambak udang di daerah Kabupaten Barru untuk budidaya tambak intensif 3,5 ton/ha/musim tanam dan tambak semi intensif 1,7 ton/ha/musim tanam, maka maksimum produksi udang yanng mampu didukung untuk kegiatan usaha tambak udang secara intensif yaitu 767 ton/musim atau 818 ton/musim untuk tambak udang semi intensif. Kemampuan daya dukung suatu kawasan pesisir untuk menampung kegiatan usaha pertambakan secara rinci disajikan pada Tabel 6.

\section{KESIMPULAN}

Berdasarkan hasil dan pembahasan, dapat disimpulkan bahwa. Parameter Fisik dan kimia perairan pesisir yaitu total padatan tersuspeni (TSS) dan COD telah melampaui ambang batas persyaratan baku mutu yang diperbolehkan untuk budidaya udang windu.

Sebaran spasial parameter fisik dan kimia perairan di stasiun laut dicirikan oleh nilai kecerahan yang tinggi, stasiun pertambakan dicirikan oleh nilai $\mathrm{NO}_{2}$, fosfat dan $\mathrm{NH}_{3}$ yang tinggi, stasiun saluran pembuangan (outlet) dan muara dicirikan nilai TSS, COD dan kekeruhan yang tinggi Nilai parameter fisik, kimia perairan lainnya menunjukkan distribusi yang hampir merata di seluruh stasiun. Stasiun pantai dan sungai tidak mencirikan nilai paramater fisik dan kimia perairan.

Parameter biologi perairan yaitu Komposisi kelas dan kelimpahan fitoplankton, kelas Bacyllariophycea merupakan jenis fitoplankton yang dominan $(75,2 \%)$, selanjutnya Cyanophyceae (9.3\%); Chlorophyceae (8.9\%); Dyanophyceae (5,9\%) dan Euglenophyceae $(0,7 \%)$. Distribusi berdasarkan stasiun (laut, pantai, tambak dan saluran pembuangan (outlet) didominasi oleh kelas Bacyllariophyceae. Sedangkan stasiun muara didominasi oleh kelas Cyanophyceae. Indeks keragaman ( $\left.H^{\prime}\right)$ dan indeks keseragaman( $E$ ) dari semua stasiun diperoleh kisaran nilai indek keragaman 1.012.12. Nilai keragaman yang terendah didapatkan pada stasiun muara dan tertinggi pada stasiun laut.

Kemampuan (daya dukung) perairan pesisir untuk menampung limbah organik berdasarkan ketersediaan oksigen yaitu 506,437 kg. Berdasarkan daya dukung

Tabel 6. Kapasitas Produksi Udang dan Luas Tambak yang Layak untuk Dioperasikan Berdasarkan Tingkat Teknologi yang didasarkan atas ketersediaan oksigen dengan limbah organik

\begin{tabular}{lcccc}
\hline \multicolumn{1}{c}{ Teknologi } & $\begin{array}{c}\text { Buangan Limbah } \\
\text { Organik (kg/ha) }\end{array}$ & $\begin{array}{c}\text { Luasan tambak } \\
\text { Yang diperboleh-kan (ha) }\end{array}$ & $\begin{array}{c}\text { Daya Dukung } \\
\text { Perairan (kg) }\end{array}$ & $\begin{array}{c}\text { Daya Dukung Produks } \\
\text { Udang (ton) }\end{array}$ \\
\hline Intensif & $2.312,15$ & 219 & & $767-818$ \\
Semi Intensif & $1.053,12$ & 481 & 506.473 & 7673 \\
\hline
\end{tabular}


tersebut, maka luas areal tambak yang layak dioperasikan/direkomendasikan di daerah Kabupaten Barru yaitu 219 ha tambak intensif atau 481 tambak semi intensif. dengan maksimum produksi udang yaitu masing-masing 767 ton/musim (tambak intensif) atau 818 ton/musim (tambak semi intensif).

\section{UCAPAN TERIMA KASIH}

Penulis mengucapkan terima kasih kepada Bapak Rektor, Ketua Lembaga Penelitian, Dekan dan ketua jurusan Budidaya Perairan Universitas Muslim Indonesia Makassar yang telah memberikan dukungan dalam pelaksanaan penelitian serta Dinas Kelautan dan Perikanan Kabupaten Barru yang telah membantu dan menfasilitasi penelitian di lapangan.

\section{DAFTAR PUSTAKA}

Annachhtre, A.P. \& Jeganaesan. J. 2006. Enviromental Impact of Shrimp Farming in Thailand. Urban enviromental engineering and management programme Asian Institute of Technology. Thailand .www.arrpet.aif.ac. th/wwtm/ml/1.pdf (13 November, 2006).

Boyd, C.E., Massaut, L. \& Weddig, L.J. 1998. Towards reducing environmental impacts of pond aquaculture. INFOFISH International 2(98): 27-33.
Boyd, C.E. 1999. Management of shrimp ponds to reduce the eutrophication potential of effluents. The Advocate, 12-13.

Dahuri, R. 1998. Tipologi lingkungan pesisir. Makalah Disajikan pada Pelatihan Analisis Mengenai Dampak Lingkungan dan Audit Lingkungan bagi Pengelolaan Lingkungan Hidup di Indonesia, PPSML UI, Jakarta, 28 - 30 Oktober 1998.

Effendi, I. 1998. Ekosistem Pertambakan dan Pelestarian Produktivitasnya. Makalah disampaikan Pelatihan Singkat Perlindungan Lingkungan Mangrove dan Tambak Suatu Upaya Pelestarian Produksi Ekosistem Mangrove dan Tambak. Pusat Kajian Sumberdaya Pesisir dan Laut (PKSPL) IPB. Bogor.

Paez-Ozuna, F., Guererro-Galvan. \& Ruiiz-Fernandez, S.R. 1998. The Enviromental impact of shrimp Aquaculture and The coastal pollution in Mexico. Marine Pollution Bulletin 36(1): $65-75$.

Primavera, J.H. \& Apud, F.F. 1994. Pond culture of sugpo (Penaeus monodon, Fabricius). Philipp. J. Fish. 18(5): 142 176.

Rahmansyah. 2004, Analisis daya dukung kawasan pesisir teluk Awarange Kabupaten Barru untuk pengembangan usaha budidaya ikan bandeng dalam Keramba jaring apung. Disertasi IPB. Bogor:Insitut Pertanian Bogor.

Soewardi, K. 2002. Pengelolaan Kualitas Air Tambak, Makalah Dalam Seminar Penetapan Standar Kualitas Air Buangan Tambak, Ditjen Perikanan Budidaya, Puncak, 7-9 Agustus 2002.

Widigdo, B. 2000. Diperlukan Pembakuan Kriteria Eko-Biologis Untuk Menentukan "Potensi Alami" Kawasan Pesisir Untuk Budidaya Udang. Prosiding. Pelatihan untuk Pelatih Pengelolaan Wilayah Pesisir Terpadu. PKSPL-IPB. Bogor 21-26 Februari 2000.

Widigdo, B, J. Haluan. \& S. Haryadi. 2001. Materi Kuliah Pengembangan Perikanan Pesisir. Program Pascasarjana Institut Pertanian Bogor (IPB). Bogor. 